\title{
Vortex-averaged Arctic ozone depletion in the winter 2002/2003
}

\author{
T. Christensen ${ }^{1}$, B. M. Knudsen ${ }^{1}$, M. Streibel ${ }^{2}$, S. B. Andersen ${ }^{1}$, A. Benesova ${ }^{3}$, G. Braathen ${ }^{4}$, H. Claude ${ }^{5}$ J. Davies $^{6}$, \\ H. De Backer ${ }^{7}$, H. Dier ${ }^{8}$, V. Dorokhov ${ }^{9}$, M. Gerding ${ }^{10}$, M. Gil ${ }^{11}$, B. Henchoz ${ }^{12}$, H. Kelder ${ }^{13}$, R. Kivi ${ }^{14}$, E. Kyrö ${ }^{14}$, \\ Z. Litynska ${ }^{15}$, D. Moore ${ }^{16}$, G. Peters ${ }^{8}$, P. Skrivankova ${ }^{3}$, R. Stübi ${ }^{12}$, T. Turunen ${ }^{14}$, G. Vaughan $^{17}$, P. Viatte ${ }^{12}$, A. F. Vik ${ }^{4}$, \\ P. von der Gathen ${ }^{2}$, and I. Zaitcev ${ }^{9}$ \\ ${ }^{1}$ Danish Meteorological Institute, Copenhagen, Denmark \\ ${ }^{2}$ Alfred Wegener Institute for Polar and Marine Research,Potsdam, Germany \\ ${ }^{3}$ Czech Hydrometeorological Institute, Prague, Czech Republic \\ ${ }^{4}$ Norwegian Institute for Air Research, Kjeller, Norway \\ ${ }^{5}$ Deutscher Wetterdienst, Hohenpeißenberg, Germany \\ ${ }^{6}$ Environment Canada, Downsview, Ontario, Canada \\ ${ }^{7}$ Royal Meteorological Institute, Brussels, Belgium \\ ${ }^{8}$ Deutscher Wetterdienst, Lindenberg, Germany \\ ${ }^{9}$ Central Aerological Observatory, Dolgoprudny, Moscow Region, Russia \\ ${ }^{10}$ Leibniz-Institue of Atmospheric Physics, Kühlungsborn, Germany \\ ${ }^{11}$ Instituto Nacional de Téchnica Aerospacial, Madrid, Spain \\ ${ }^{12}$ MeteoSwiss, Payerne, Switzerland \\ ${ }^{13}$ Royal Netherlands Meteorological Institute, De Bilt, Netherlands \\ ${ }^{14}$ Finnish Meteorological Institute, Sodankylä, Finland \\ ${ }^{15}$ IMWM, Centre of Aerology, Legionowo, Poland \\ ${ }^{16}$ UK Met Office, Exeter, UK \\ ${ }^{17}$ University of Wales, Aberystwyth, UK
}

Received: 25 August 2004 - Published in Atmos. Chem. Phys. Discuss.: 19 October 2004

Revised: 10 January 2005 - Accepted: 17 January 2005 - Published: 21 January 2005

\begin{abstract}
A total ozone depletion of $68 \pm 7$ Dobson units between 380 and $525 \mathrm{~K}$ from 10 December 2002 to 10 March 2003 is derived from ozone sonde data by the vortex-average method, taking into account both diabatic descent of the air masses and transport of air into the vortex. When the vortex is divided into three equal-area regions, the results are $85 \pm 9 \mathrm{DU}$ for the collar region (closest to the edge), $52 \pm 5 \mathrm{DU}$ for the vortex centre and $68 \pm 7 \mathrm{DU}$ for the middle region in between centre and collar.

Our results compare well with other studies: We find good agreement with ozone loss deduced from $\mathrm{SAOZ}$ data, with results inferred from POAM III observations and with results from tracer-tracer correlations using $\mathrm{HF}$ as the longlived tracer. We find a higher ozone loss than that deduced by tracer-tracer correlations using $\mathrm{CH}_{4}$.

We have made a careful comparison with Match results: The results were recalculated using a common time period, vortex edge definition and height interval. The two methods generally compare very well, except at the $475 \mathrm{~K}$ level which exhibits an unexplained discrepancy.
\end{abstract}

Correspondence to: T. Christensen

(tic@dmi.dk)

\section{Introduction}

The ozone content in the Arctic stratosphere is dependent on chemical and dynamical conditions and shows great interannual variability. Chemical ozone loss occurs during winter when the polar vortex isolates air masses which exhibit significantly lower average temperatures than the air surrounding the vortex. In very cold conditions polar stratospheric clouds (PSCs) can form and in sunlit conditions give rise to large chemical ozone losses. The formation, evolution and break-up of the vortex as well as the occurence of stratospheric warmings are subject to huge variations from each winter to the next.

The amount of column ozone in the Arctic decreased and exhibited increased variability in the period 1992-2000, and the major part of both the decrease and variability in March can be explained by chemical ozone destruction in winter and spring (Andersen and Knudsen, 2002). Likewise, observations presented by Rex et al. (2004) indicate that about half of the interannual ozone variability is due to chemical ozone destruction. During the past four decades the coldest winters, where extreme ozone losses occur, have grown colder, and the record volume coverage of PSCs has increased steadily.

(C) 2005 Author(s). This work is licensed under a Creative Commons License. 
Table 1. The limits defining the vortex edge at eight different potential temperature levels. The limits are given as modified potential vorticity (MPV) in units of PVU.

\begin{tabular}{lcccccccc}
\hline & $350 \mathrm{~K}$ & $380 \mathrm{~K}$ & $400 \mathrm{~K}$ & $435 \mathrm{~K}$ & $475 \mathrm{~K}$ & $525 \mathrm{~K}$ & $600 \mathrm{~K}$ & $675 \mathrm{~K}$ \\
\hline 20 Dec. 2002 & 32.0 & 28.7 & 29.4 & 30.2 & 32.9 & 37.2 & 50.5 & 31.1 \\
30 Dec. 2002 & 32.2 & 28.6 & 29.2 & 30.1 & 32.7 & 33.2 & 31.4 & 39.5 \\
9 Jan. 2003 & 32.4 & 30.2 & 30.8 & 32.0 & 36.5 & 32.3 & 37.1 & 40.9 \\
19 Jan. 2003 & 33.4 & 31.1 & 32.3 & 35.6 & 37.8 & 39.2 & 42.1 & 37.6 \\
29 Jan. 2003 & 33.3 & 29.6 & 30.3 & 33.2 & 38.5 & 36.7 & 40.8 & 37.5 \\
8 Feb. 2003 & 33.2 & 29.9 & 30.9 & 33.4 & 36.2 & 36.9 & 38.7 & 41.3 \\
18 Feb. 2003 & 33.7 & 29.7 & 31.8 & 36.0 & 38.3 & 37.8 & 37.9 & 39.6 \\
28 Feb. 2003 & 33.7 & 30.4 & 33.4 & 36.3 & 37.8 & 40.2 & 39.5 & 38.9 \\
10 Mar. 2003 & 33.2 & 29.1 & 30.2 & 32.3 & 40.4 & 35.8 & 35.9 & 39.1 \\
\hline
\end{tabular}

The reason for this change in polar vortex climate conditions is not entirely explained. An empirical linear relation between PSC volume and chemical polar ozone loss is reported by Rex et al. (2004) who conclude that about 15 Dobson units additional ozone loss can be expected for each Kelvin of average Arctic stratospheric cooling. The detailed mechanisms of chemical ozone loss in the Arctic and the connection to climate change seems to be insufficiently explained by current models, stressing the importance of continued research in Arctic ozone losses.

December 2002 was characterized by very low temperatures and large areas of possible PSC existence were deduced by Tilmes et al. (2003). Around mid-January 2003 the vortex became perturbed, and during 19-21 January 2003 the vortex was split in two. In early February 2003, the vortex became more symmetrical, only to experience another splitting around 20 Feburary 2003, into two parts that reunited on 22 February 2003. The vortex eventually broke down around mid-April 2003.

In order to determine the chemical ozone loss from the observational data it is important to separate the effect of dynamics affecting the ozone content. There are two main approaches: Transport can be determined by measurements of long-lived inert tracers or by Langrangian trajectory calculations based on meteorological analyses. A description of five different methods is given by Harris et al. (2002) along with a careful comparison: Using the same regions and time periods for the four different Lagrangian approaches they found good agreement between the methods; better than otherwise seen in the literature. In this work we use an approach known as the vortex-average technique (Harris et al., 2002, and references therein) to filter out the transport. From a large number of trajectories on selected isentropic surfaces the average vertical advection of the vortex-averaged ozone profile is calculated. Our resulting ozone losses are compared to results from tracer-tracer correlations, SAOZ data and POAM III observations, and a careful comparison with Match results is accomplished by a recalculation of results.

\section{Vortex area definitions}

Equivalent latitude and potential vorticity (PV) criteria are used to define the extent of the Arctic vortex. The equivalent latitude of an air parcel is the latitude encompassing the same poleward area as the PV-contour through the parcel.

The PV value exhibiting the largest gradient in PV as a function of equivalent latitude is used as the edge of the vortex. In case of multiple maxima within $10 \%$ of each other the PV value closest to the previous day is used. If the PV gradient with respect to equivalent latitude is smaller than $1 \mathrm{PVU} /$ degree (1 PVU $=10^{-6} \frac{\mathrm{K} \mathrm{m}^{2}}{\mathrm{~s} \mathrm{~kg}}$ ) for an isolated point, the average PV value of the previous and the next day is used. If two or more points have a gradient below this limit, the vortex is considered broken down or not yet established. In such cases the PV value of the "edge" is determined such that the equivalent latitude is the same as for the level above. This method of determining the edge of the vortex is quite similar to that of Nash et al. (1996), but simpler to use because wind fields are not necessary.

At $475 \mathrm{~K}$ and above the vortex was established by $10 \mathrm{De}-$ cember 2002, and did not break down before April. At $435 \mathrm{~K}$ the vortex was established on 2 January 2003. At $400 \mathrm{~K}$ and below no vortex existed at any time in the winter 2002/2003.

In Table 1 the PV values defining the vortex edge by the above criteria are given using modified potential vorticity (MPV) defined as (Lait, 1994):

$\mathrm{MPV}=\mathrm{PV}\left(\frac{\theta}{475 \mathrm{~K}}\right)^{-\frac{9}{2}}$,

where $\theta$ is the potential temperature.

The vortex is divided into three equal-area regions depending on potential vorticity. The lowest potential vorticity region, closest to the edge is called the collar, the region with highest potential vorticity is called the centre and the region in between is called the middle. The vortex regions at $475 \mathrm{~K}$ are depicted in Fig. 1, and it can be seen that the regions, as in this case where the vortex is highly elongated, can have odd shapes and discontinuities. 


\section{Observations}

The full data set available for this study comprises 603 ozone sondes from 25 stations north of $45^{\circ} \mathrm{N}$ in the period from 2 November 2002 to 28 March 2003.

For each sonde the ozone mixing ratio is calculated at eight potential temperature levels $(\theta=350,380,400,435,475,525$, 600 and $675 \mathrm{~K}$ ) from the median of all measured values of the ozone partial pressure in a $\pm 5 \mathrm{~K} \theta$ interval.

The potential vorticity corresponding to each ozone mixing ratio value is derived from European Centre for MediumRange Weather Forecasts (ECMWF) analyses.

From the full ozone sonde data set a mapping of ozone mixing ratio as a function of potential vorticity and potential temperature is made, cf. Lary et al. (1995, and references therein). Sobel et al. (1997) showed that reverse domainfilling trajectory calculations tend to give substantial spurious transport into the vortex due to errors in the analyzed $\mathrm{PV}$. This is partially avoided here by centering the PV bins used in the PV- $\theta$ mapping at the edge of the vortex (Knudsen et al., 1998). Eight bins of $6 \mathrm{PVU}$ width centered on $0, \pm 6$, $\pm 12, \pm 18$ and $-24 \mathrm{PVU}$ relative to the vortex edge (positive values are inside the vortex) are used.

Only data from the period 10 December 2002 to 10 March 2003 for points within the vortex, as determined by the PV value at each $\theta$ level, are used in the ozone depletion calculations. Not all sondes have successful measurements at all eight $\theta$ levels. At $475 \mathrm{~K}$ that leaves 201 sondes.

\section{Ozone depletion calculations}

\subsection{Diabatic descent}

Values obtained early and late in winter at the same $\theta$ level cannot be directly compared. Over such a long time interval the diabatic cooling, which is causing a slow descent of air masses across the isentropic surfaces, must be taken into account. Air masses that on 10 March 2003 are at the isentropic surface of $475 \mathrm{~K}$ have on average descended from a potential temperature of $556 \mathrm{~K}$ since 10 December 2002. This diabatic cooling was calculated along Langrangian trajectories using a reverse domain-filling trajectory approach. The calculations use six hourly ECMWF analyses in a $1.5^{\circ}$ latitude-longitude grid based on a T79 truncation. The reverse domain-filling trajectory calculations (Knudsen and Grooss, 2000) are perfomed in an equal-area grid with a grid distance of $1^{\circ}$ by latitude $(\sim 111 \mathrm{~km})$. The calculations are started on the eight aforementioned potential temperature levels and performed ten days backwards in time. The calculations are three-dimensional as the potential temperature is changed by the diabatic heating in each time step. Heating rate calculations are done for clear-sky conditions using the version of the ECMWF radiation scheme (Morcrette, 1991) which became operational in September 2000.

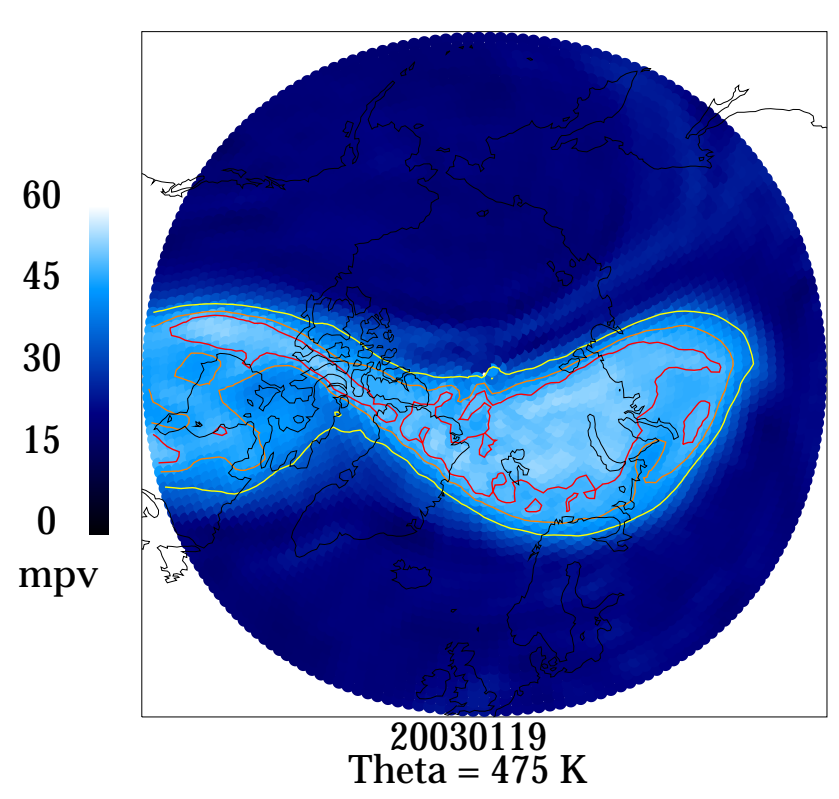

Fig. 1. Modified potential vorticity MPV north of $50^{\circ} \mathrm{N}$ in units of PVU at $\theta=475 \mathrm{~K}$ on 19 January 2003 from ECMWF analyses. The yellow contour line shows the vortex edge, the orange contour line shows the limit between the vortex collar and middle and the red contour line shows the limit between the vortex middle and centre.

The ozone mixing ratios used in the heating rate calculations are obtained from the PV- $\theta$ mapping (described in Sect. 3) of the ozone data. The water vapour mixing ratio used is 4 ppmv from 350 to $400 \mathrm{~K}, 7$ ppmv above $625 \mathrm{~K}$, and a linear variation in between (Müller et al., 2003). Below $350 \mathrm{~K}$ the ECMWF water vapour mixing ratio is used.

The accuracy of our diabatic cooling has been checked against tracer descent lines from Greenblatt et al. (2002) for the winter 1999/2000 vortex. The comparison is shown in Fig. 2. With climatological ozone from Fortuin and Kelder (1998) we obtain a descent from 11 January to 15 March 2000 which is substantially closer to the tracer descent lines than the SLIMCAT (Chipperfield, 1999) model results presented by Greenblatt et al. (2002).

Taking tracer mixing into account would increase the tracer descent above the bottom levels (Ray et al., 2002), but using actual ozone instead of a climatology would probably also increase the modelled descent, to some extent cancelling the effect. For the 2002/2003 calculations for the period 10 December 2002 to 10 March 2003 the descent to the $475 \mathrm{~K}$ level is $81 \mathrm{~K}$ using observed ozone and $68 \mathrm{~K}$ using the ozone climatology.

The diabatic cooling ten days back in time was calculated for air masses ending inside the vortex. Figure 3 shows the calculated diabatic cooling for each of the three vortex areas (defined in Sect. 2) for the period 10 December 2002 to 10 March 2003. 
Table 2. Transport of air from outside the vortex into the vortex collar at the $475 \mathrm{~K}$ isentropic level. The dates are where the air masses end, i.e. where the trajectory calculations ten days back in time begin. The column Entry gives the percentage of trajectories with air masses ending in the collar that originated from outside the vortex. Sample is the total number of trajectories with air masses ending in the collar. The next three columns give the average mixing ratio as deduced for the entering air mass, $\chi_{\text {influx }}$, as observed for the vortex collar, $\chi_{o b s}$, and the mixing ratio obtained after correcting for the influx, $\chi_{\text {corr }}$. The last column gives the change in mixing ratio due to the correction.

\begin{tabular}{lrccccr}
\hline Date & Entry & Sample & \multicolumn{3}{c}{ Mixing ratio (ppmv) } & Change \\
& & & $\chi_{\text {influx }}$ & $\chi_{\text {obs }}$ & $\chi_{\text {corr }}$ & $|\Delta \chi|$ \\
\hline 20 December 2002 & $14 \%$ & 674 & 2.51 & 2.94 & 3.01 & $2 \%$ \\
30 December 2002 & $9 \%$ & 678 & 2.96 & 3.05 & 3.06 & $<1 \%$ \\
9 January 2003 & $2 \%$ & 584 & 2.71 & 2.68 & 2.68 & $<1 \%$ \\
19 January 2003 & $8 \%$ & 411 & 2.91 & 2.56 & 2.53 & $1 \%$ \\
29 January 2003 & $22 \%$ & 493 & 2.82 & 2.54 & 2.47 & $3 \%$ \\
8 February 2003 & $5 \%$ & 514 & 2.71 & 2.35 & 2.34 & $<1 \%$ \\
18 February 2003 & $16 \%$ & 403 & 2.66 & 2.37 & 2.31 & $3 \%$ \\
28 February 2003 & $6 \%$ & 416 & 2.94 & 2.39 & 2.36 & $1 \%$ \\
10 March 2003 & $6 \%$ & 325 & 2.38 & 2.60 & 2.61 & $<1 \%$ \\
\hline
\end{tabular}

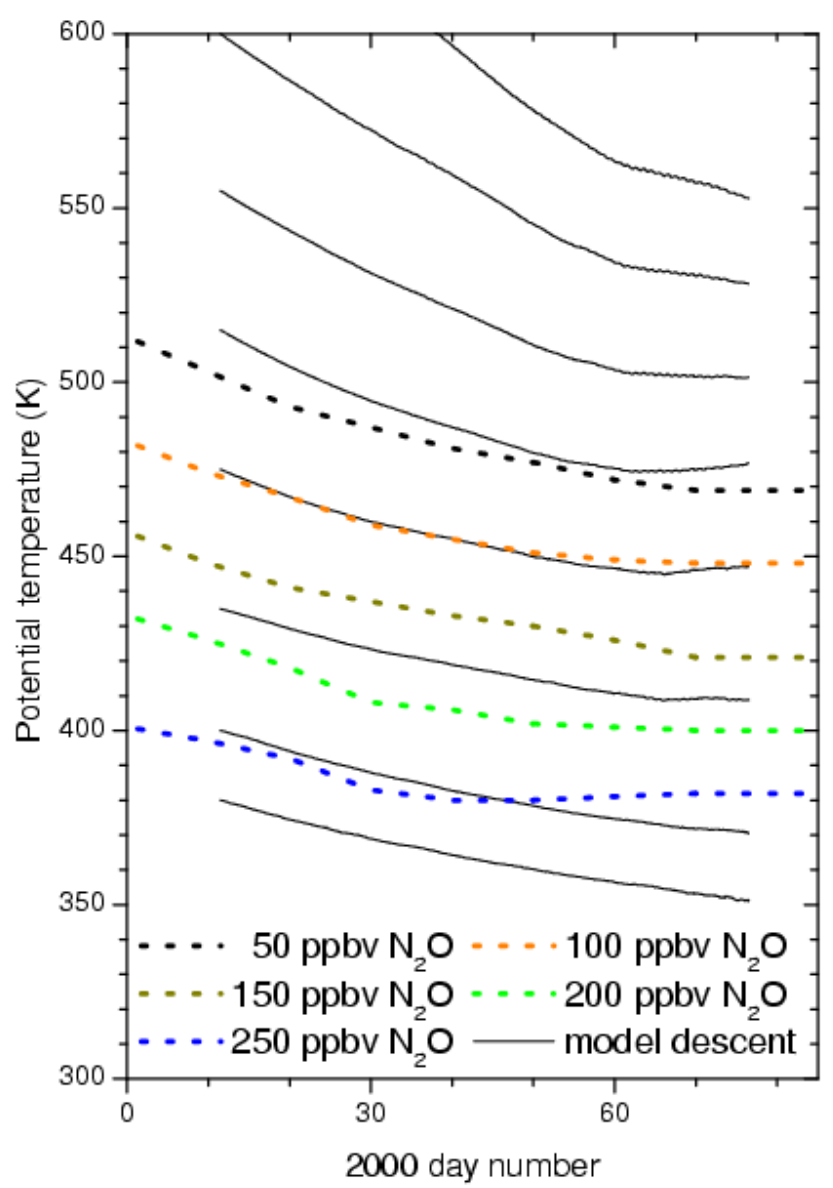

Fig. 2. Comparison of the $\mathrm{N}_{2} \mathrm{O}$ descent lines from Greenblatt et al. (2002) and our modelled diabatic descent for the whole vortex (solid black lines) based on climatological ozone for the winter 1999/2000 vortex.

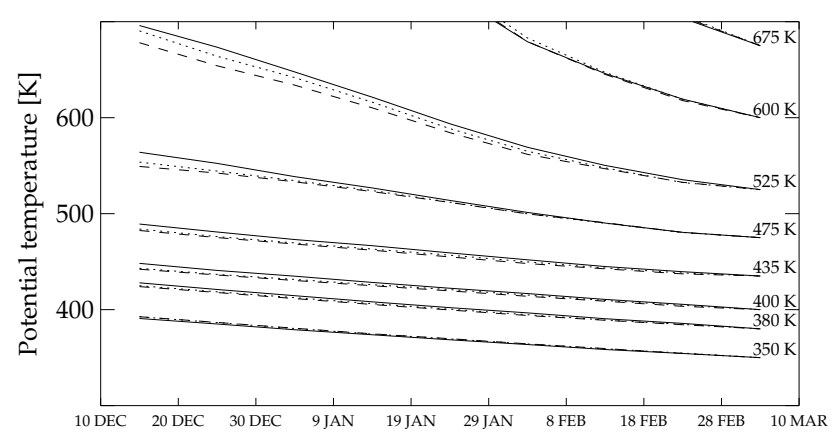

Fig. 3. Diabatic cooling during the winter $2002 / 2003$ calculated along Lagrangian trajectories ten days back in time for air masses ending in the vortex. Solid line: vortex collar. Dotted line: vortex middle. Dashed line: vortex centre.

\subsection{Transport into the vortex}

Air from lower latitudes is to some extent transported across the vortex edge. When the vortex-averaged ozone mixing ratio at the beginning and end of winter are compared to each other in order to determine the chemical ozone depletion, the amount of transport into the vortex must be taken into account.

The vortex-averaged mixing ratios, $\chi_{o b s}$, for each $\theta$ level is calculated from ozone measurements within each vortex area at the end of each ten day period. The percentages of trajectories where air masses ending in the collar stem from outside the vortex, are given in Table 2 for $\theta=475 \mathrm{~K}$. At this isentropic level the transport from outside the vortex into the middle and centre regions of the vortex is never more than $3 \%$. In Table 2 are also given the average ozone mixing ratio for the entering air parcels, $\chi_{\text {influx }}$, estimated by interpolation of the PV- $\theta$ mapping (described in Sect. 3), and the 


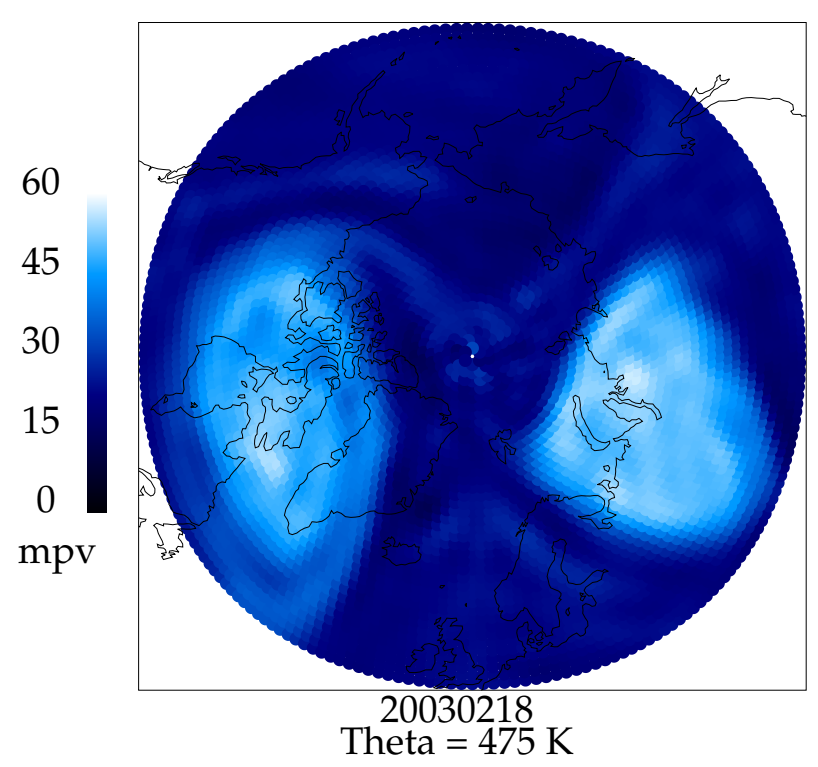

Fig. 4. The splitting of the vortex on 18 February 2003. Modified potential vorticity MPV in units of PVU at $\theta=475 \mathrm{~K}$ from ECMWF analyses.

average mixing ratio for the area, as calculated from ozone measurements, $\chi_{o b s}$. One trajectory had a PV value falling outside the PV range of the mapping. In this single case the ozone mixing ratio corresponding to the closest $\mathrm{PV}$ value within the mapping was used in order to avoid extrapolation.

A corrected ozone mixing ratio, $\chi_{\text {corr }}$, considered to represent the air masses that remained within the vortex and was subject to chemical ozone depletion, is calculated as:

$\chi_{\text {corr }}=\frac{\chi_{o b s}-r \chi_{\text {influx }}}{1-r}$,

where $r$ is the number of trajectories entering the vortex area from outside relative to the total number of trajectories ending in the vortex area. This ratio, $r$, is given as a percentage in Table 2 for the vortex collar at $\theta=475 \mathrm{~K}$. The last two columns in Table 2 show the corrected ozone mixing ratio, $\chi_{c o r r}$, and the difference between $\chi_{c o r r}$ and $\chi_{o b s}$ which does not exceed $3 \%$.

The corrected vortex-averaged ozone mixing ratio is used when calculating the total ozone depletion. If a trajectory starts in the vortex, leaves and re-enters the vortex within the same ten day period, that trajectory is counted as if it stayed within the vortex the whole time. If a trajectory leaves the vortex and re-enters in a later ten day period, it is counted as an outside entry in the latter period, and not counted at all in the first period.

The highest entry rate at $475 \mathrm{~K}$ is found on 29 January 2003 , where $22 \%$ of the trajectories show air masses crossing the vortex edge and entering the collar. During the 10 day period 19-29 January the vortex is highly disturbed (see Fig. 1), actually splitting into two parts during 19-21 January
Table 3. Vortex-averaged ozone depletion from 10 December 2002 to 10 March 2003. The depletion rates for the collar, middle and centre regions in units of ppbv/day are derived from the best linear fits displayed in Fig. 5. The depletion rates for the whole vortex are likewise derived from best linear fits. The quoted uncertainties are the one sigma standard deviations of the linear fits.

\begin{tabular}{rrrrr}
\hline$\theta$ & $\begin{array}{r}\text { Whole vortex } \\
\text { ppbv/day }\end{array}$ & $\begin{array}{r}\text { Vortex collar } \\
\text { ppbv/day }\end{array}$ & $\begin{array}{r}\text { Vortex middle } \\
\text { ppbv/day }\end{array}$ & $\begin{array}{r}\text { Vortex centre } \\
\text { ppbv/day }\end{array}$ \\
\hline 525 & $-5.3 \pm 2.0$ & $-12.0 \pm 2.6$ & $-1.5 \pm 1.6$ & $-2.5 \pm 0.9$ \\
475 & $-11.2 \pm 1.5$ & $-14.9 \pm 2.7$ & $-9.1 \pm 1.1$ & $-9.5 \pm 1.6$ \\
435 & $-13.9 \pm 0.7$ & $-16.9 \pm 1.4$ & $-12.6 \pm 0.9$ & $-12.3 \pm 0.7$ \\
400 & $-10.9 \pm 0.8$ & $-10.4 \pm 1.6$ & $-12.7 \pm 1.1$ & $-9.8 \pm 0.8$ \\
380 & $-10.0 \pm 1.1$ & $-9.0 \pm 2.4$ & $-11.0 \pm 1.9$ & $-9.9 \pm 1.2$ \\
350 & $-4.7 \pm 2.0$ & $-4.3 \pm 1.7$ & $-6.5 \pm 1.1$ & $-7.0 \pm 0.9$ \\
\hline
\end{tabular}

Table 4. Vortex-averaged column ozone depletion in Dobson units between 380 and $525 \mathrm{~K}$ from 10 December 2002 to 10 March 2003.

\begin{tabular}{cccc}
\hline Whole vortex & Vortex collar & Vortex middle & Vortex centre \\
\hline $68 \pm 7 \mathrm{DU}$ & $85 \pm 9 \mathrm{DU}$ & $68 \pm 7 \mathrm{DU}$ & $52 \pm 5 \mathrm{DU}$ \\
\hline
\end{tabular}

(Tilmes et al., 2003). On 18 February 2003, the transport into the collar is also high: $16 \%$. On this day the vortex is also split into two parts, see Fig. 4. At both these times of very high entry rate the vortex is highly disturbed, and the air entering from outside the vortex actually has estimated ozone mixing ratios $0.4-0.7$ ppmv higher than the collar-average.

\section{Results}

Ozone mixing ratios are binned into ten-day intervals and into the potential vorticity bins representing the vortex collar, middle and centre. The average ozone mixing ratio calculated for each bin, corrected for diabatic descent and the effect of transport into the vortex, are shown in Fig. 5 for six potential temperature levels. With these two effects removed it is reasonable to ascribe the remaining decrease in ozone mixing ratio over time to chemical ozone depletion. The best linear fits to the data points results in the depletion rates given in Table 3 . The uncertainties given are the standard deviations of the linear fits.

The integrated column ozone loss from $380 \mathrm{~K}$ to $525 \mathrm{~K}$ from 10 December 2002 to 10 March 2003, calculated from the depletion rates in Table 3 is given in Table 4 . The vertical integration of the ozone column loss is approximated by a sum, cf. Atkinson and Plumb (1997, their Eq. A5). It is assumed that no chemical ozone loss take place above $525 \mathrm{~K}$ 


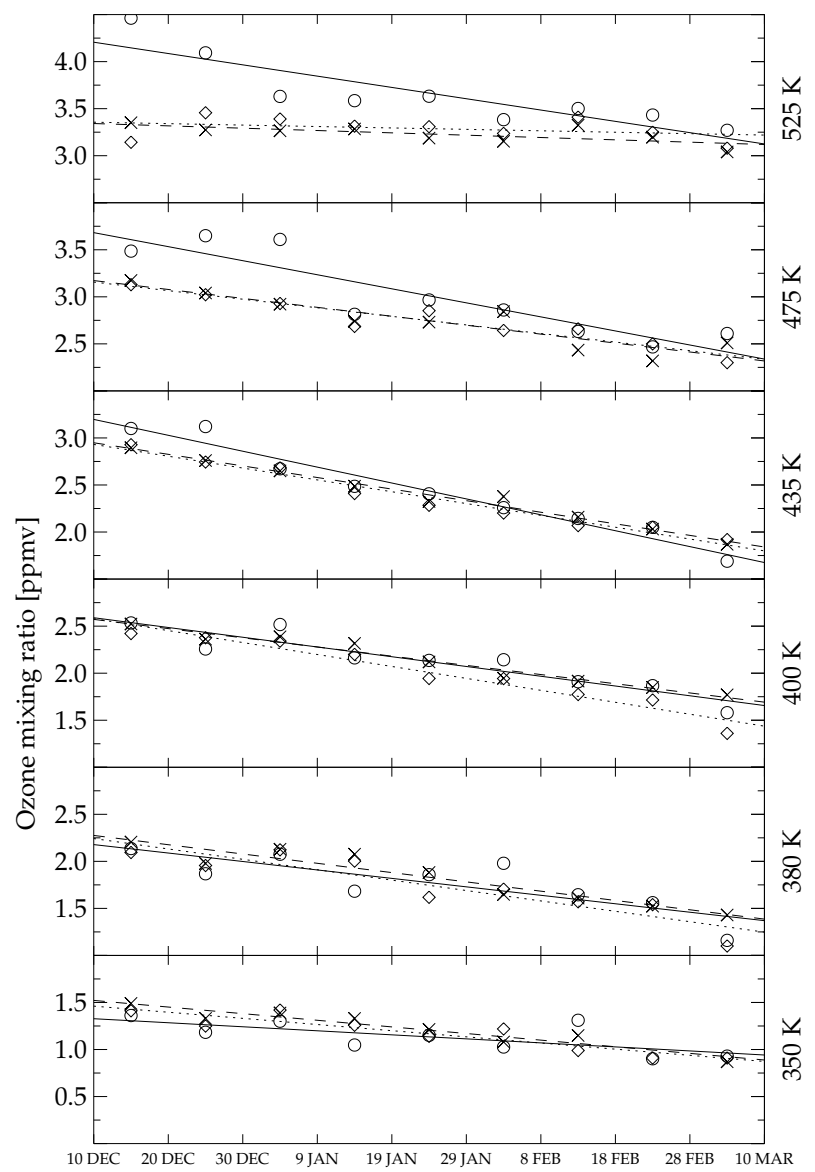

Fig. 5. Ozone mixing ratios, averaged over ten-day intervals and over vortex areas (collar, middle and centre), corrected for diabatic descent and transport into the vortex. Linear best fits to the data are shown for each area and each of $\operatorname{six} \theta$ levels. Circles: vortex collar. Diamonds: vortex middle. Crosses: vortex centre. Solid lines: vortex collar. Dotted lines: vortex middle. Dashed lines: vortex centre.

and below $380 \mathrm{~K}$, but actually there may have been a small amount of chemical ozone depletion at $350 \mathrm{~K}$ since the depletion rate found is non-zero. Calculating the column ozone loss from $350 \mathrm{~K}$ to $525 \mathrm{~K}$ averaging over the whole vortex gives $94 \pm 9 \mathrm{DU}$. The fact that no vortex existed at $400 \mathrm{~K}$ and below impairs the confidence in the calculations at these levels, but does not entirely remove their significance.

The uncertainties in the calculations of transport into the vortex are mainly caused by errors in the calculated PV (Sobel et al., 1997). In order to estimate how sensitive the PV- $\theta$ mapping is to PV errors, calculations were done with double bin size (12 PVU) and with half bin size (3 PVU). These calculations resulted in ozone loss rates and height-integrated ozone loss within $4 \%$ of the presented results.

The accuracy of the calculations of diabatic descent are hard to assess, but we have tested the sensitivity of the results presented above to errors in the cooling: If the amount of cooling is changed by $\pm 20 \%$, the slopes in Fig. 5 are changed by less than $20 \%$ for the levels $380-475 \mathrm{~K}$ and by $30-40 \%$ for 350 and $525 \mathrm{~K}$, while the height-integrated ozone loss is changed by $10-15 \%$. Errors in the cooling is probably the most important factor in determining the uncertainty. Overall an uncertainty of $10 \%$ for the height-integrated ozone loss is adopted.

\section{Comparison with other results}

Using tracer-tracer correlations with $\mathrm{HF}$ as the long-lived tracer, Tilmes et al. (2004) find a column ozone loss (380 $550 \mathrm{~K}$ ) of $37 \pm 9 \mathrm{DU}$ from 16 December 2002 to 25 February 2003, and 44 \pm 10 DU from 16 December 2002 to 19 April 2003, using the vortex definition of Nash et al. (1996). The height range and vortex edge definitions are very close to ours, but the derived ozone losses for both periods are considerably less than the $68 \pm 7 \mathrm{DU}$ found in this work for 10 December 2002 to 10 March 2003. Using $\mathrm{CH}_{4}$ as the chemical tracer, Tilmes et al. (2004) find instead $66 \pm 12$ and $71 \pm 13 \mathrm{DU}$, respectively, for the two periods and the same height range as for HF. These values agree with our results, but Tilmes et al. (2004) note that the $\mathrm{CH}_{4}$ mixing ratios for 2002/2003 may be problematic due to signal saturation problems.

From SAOZ measurements of the total ozone columns at seven Arctic stations an ozone loss of $90 \mathrm{DU}$ is calculated using transported passive ozone from the chemical transport model REPROBUS by Goutail et al. (2004) for the period 1 December 2002 to 10 March 2003 using the vortex edge definition of Nash et al. (1996) at the $475 \mathrm{~K}$ level to determine whether a particular station was within the vortex. This is slightly larger than our result of $68 \pm 7 \mathrm{DU}$ which is for a similar period and vortex definition. The discrepancy might be explained by the difference in time period: PSC existence were predicted for 1-10 December 2002 (Tilmes et al., 2003). Also it cannot be ruled out that some ozone depletion could have occurred outside the height range studied in this work.

Singleton et al. (2004) have used the chemical transport model SLIMCAT to infer ozone losses in the Arctic vortex (as defined by Nash et al. (1996)) from POAM III satellite observations of ozone for the period 1 December 2002 to 15 March 2003. We find quite good agreement when we compare our results for the whole vortex to their results from the Pure Passive SLIMCAT runs: For the $\theta$ levels 400, 435, 475 and $525 \mathrm{~K}$ Singleton et al. (2004, their Fig. 9) find ozone losses of about 0.7, 1.2, 1.0 and 0.7 ppmv, respectively, (having subtracted the $0.3 \mathrm{ppmv}$ bias due to initialization errors from the values read from the figure), while we find $1.0 \pm 0.1$, $1.3 \pm 0.1,1.0 \pm 0.2$ and $0.5 \pm 0.3 \mathrm{ppmv}$, respectively (the uncertainties given are based on the one sigma standard deviation of a linear fit for the whole vortex (not shown) to the ozone mixing ratios in Fig. 5.) 
Table 5. Accumulated ozone loss from 10 December 2002 to 10 March 2003 from the Match technique and recalculated with new parameters for the vortex-average method. The Match ozone loss at $389 \mathrm{~K}$ is a lower limit. The vortex-averaged column loss is calculated between 380 and $525 \mathrm{~K}$, while the Match column loss is calculated, using the six levels mentioned in the text, from 380 to $500 \mathrm{~K}$ (for both methods the integration limits are $\theta$ levels of 30 March 2003).

\begin{tabular}{ccc}
\hline$\theta(10 \mathrm{March})$ & Match ozone loss & Vortex average ozone loss \\
\hline $479 \mathrm{~K}$ & $1647 \pm 315 \mathrm{ppbv}$ & $1000 \pm 200 \mathrm{ppbv}$ \\
$433 \mathrm{~K}$ & $1374 \pm 197 \mathrm{ppbv}$ & $1250 \pm 97 \mathrm{ppbv}$ \\
$409 \mathrm{~K}$ & $1239 \pm 181 \mathrm{ppbv}$ & $1020 \pm 104 \mathrm{ppbv}$ \\
$389 \mathrm{~K}$ & $745 \pm 219 \mathrm{ppbv}$ & $1006 \pm 140 \mathrm{ppbv}$ \\
Column & $75 \pm 5 \mathrm{DU}$ & $69 \pm 7 \mathrm{DU}$ \\
\hline
\end{tabular}

\subsection{Careful comparison with Match}

The Match technique (Rex et al., 2002, and references therein) samples the same air parcel several times. From the first identification of the air parcel, trajectory calculations are used to determine later positions. Match results for the winter 2002/2003 are described by Streibel (to be submitted, $2005)^{1}$. In order to compare our results with the Match results, both Match and vortex-average results are recalculated using the same vortex edge definition, the same height range (to the extent possible) and the same time period.

The common vortex edge criteria adopted for this comparison are: The vortex edge in units of MPV is the same for all potential temperatures. From 10 December 2002 to 9 January 2003 the edge value increases monotonically from to 31 to $36 \mathrm{PVU}$, and thereafter it is fixed at $36 \mathrm{PVU}$. Due to the consistency of Match analyses from year to year, the levels available for comparison are Match air masses ending at 380, 400, 425, 450, 475 and $500 \mathrm{~K}$ on $30 \mathrm{March}$ 2003, even though the common period of comparison is 10 December 2002 to 10 March 2003 for both the Match and our approach. The Match air masses correspond to 389, 409, 433, 456, 479 and $502 \mathrm{~K}$ on 10 March 2003, and we consequently interpolate our results to air masses ending on these values. Accumulated ozone losses for the four levels relevant for comparison are listed in Table 5. Due to differences in vertical resolution comparisons are made only for the levels ending on $10 \mathrm{March}$ at 389, 409, 433 and $479 \mathrm{~K}$, those that correspond best to levels in our calculations. The Match-deduced ozone loss at $389 \mathrm{~K}$ is a lower limit, as the Match analysis does not extent below $400 \mathrm{~K}$, i.e. the integration is stopped when the $400 \mathrm{~K}$ level is reached, which happens around mid-February. The uncertainties given for the vortex-average method are the

\footnotetext{
${ }^{1}$ Streibel, M.: Chemical ozone loss in the Arctic winter 2002/2003 determined with Match, Atmos. Chem. Phys. Discuss., to be submitted, 2005.
}

standard deviations of linear fits (not shown) similar to those in Fig. 5, but with just one fit for the whole vortex at each $\theta$ level.

For the height-integrated ozone loss and for the accumulated losses at levels below $475 \mathrm{~K}$ the two methods agree, but at the $475 \mathrm{~K}$ level there is an unexplained discrepancy. The Match approach is sensitive to imhomogenities in ozone loss rate; possibly this can explain the descrepancy. The two methods deduce different amounts of diabatic descent at $475 \mathrm{~K}$, where the Match analysis finds a $45 \mathrm{~K}$ cooling, significantly less than the $81 \mathrm{~K}$ found by the method described in this work. Generally, an underestimation of the descent will lead to an underestimation of the ozone loss, but Match finds a larger ozone loss than the vortex-average method.

With the vortex-average method we find a total column loss between 380 and $525 \mathrm{~K}$ of $69 \pm 7 \mathrm{DU}$. Using the Match technique $75 \pm 5 \mathrm{DU}$ is found, integrating from 380 to $500 \mathrm{~K}$. For both methods the $\theta$ levels defining the integration limits are those of 30 March 2003.

\section{Conclusions}

Using a vortex-edge definition based on the location of the steepest gradient in potential vorticity the vortex-averaged ozone depletion for the Arctic winter and spring 2002/2003 is deduced, taking into account the dynamics that also effect the ozone content: diabatic descent of the air masses during the period and transport of air masses over the vortex edge.

The resulting total column ozone-losses presented in Table 4 are not significantly affected by air entering the vortex from outside: Without transport over the vortex edge taken into account, the ozone loss would be 3 DU less for the collar region and $1 \mathrm{DU}$ less for the whole vortex. The expected effect of transport over the vortex edge is an influx of air of lower ozone content, but under the disturbed meteorological conditions with two vortex splittings, it is possible that much of the influx is ozone-rich polar air re-entering the vortex.

Comparisons with ozone losses derived for the same period, 10 December 2002 to 10 March 2003, by the Match technique show good agreement. Great care was taken to use not only the same time period but also the same vortex edge definition and, to the extent possible, the same height interval for the recalculated results used in the comparison.

Comparisons with other results for the winter 2002/2003 show quite good agreement with the column ozone loss derived from SAOZ observations using REPROBUS (Goutail et al., 2004) and with accumulated ozone loss inferred from POAM III observations using SLIMCAT (Singleton et al., 2004). Results derived from tracer-tracer correlations for the height-integrated ozone loss using $\mathrm{HF}$ as the chemical tracer (Tilmes et al., 2004) are substantially smaller than our results, while we find very good agreement comparing to results using $\mathrm{CH}_{4}$ as the chemical tracer. 
Acknowledgements. We thank ECMWF for providing analyses and J.-J. Morcrette for making the ECMWF radiative scheme available to us. Numerous ozone sonde staff are thanked for their contribution. This work was supported by the EU fifth framework programme through the QUOBI project (EVK2-CT-2001-00129).

Edited by: K. Carslaw

\section{References}

Andersen, S. B. and Knudsen, B. M.: The influence of vortex ozone depletion on Arctic ozone trends, Geophys. Res. Lett., 29, doi:10.1029/2001GL014595, 2002.

Atkinson, R. J. and Plumb, R. A.: Three-dimensional ozone transport during the ozone hole breakup in December 1987, J. Geophys. Res., 102, 1451-1466, 1997.

Chipperfield, M. P.: Multiannual simulations with a three-dimensional chemical transport model, J. Geophys. Res., 104, 17811806, 1999.

Fortuin, P. and Kelder, H.: An ozone climatology based on ozonesonde and satellite measurements, J. Geophys. Res., 103, 31 709-31 734, 1998.

Goutail, F., Pommereau, J.-P., Lefèvre, F., Van Roozendael, M., Andersen, S. B., Kåstad Høiskar, B.-A., Dorokhov, V., Kyrö, E., Chipperfield, M. P., and Feng, W.: Early unusual ozone loss during the Arctic winter 2002/2003 compared to other winters, Atmos. Chem. Phys. Discuss., 4, 5019-5044, 2004,

\section{SRef-ID: 1680-7375/acpd/2004-4-5019.}

Greenblatt, J. B., Jost, H.-J., Loewenstein, M., Podolske, J. R., Hurst, D. F., Elkins, J. W., Schauffler, S. M., Atlas, E. L., Herman, R. L., Webster, C. R., Bui, T. P., Moore, F. L., Ray, E. A., Oltmans, S. J., Vömel, H., Blavier, J.-F., Sen, B., Stachnik, R. A., Toon, G. C., Engel, A., Müller, M., Schmidt, U., Bremer, H., Pierce, R. B., Sinnhuber, B.-M., Chipperfield, M., and Lefèvre, F.: Tracer-based determination of vortex descent in the 1999/2000 Arctic winter, J. Geophys. Res., 107, doi:10.1029/2001JD000937, (Erratum: J. Geophys. Res., 108, doi:10.1029/2001JD001597), 2002.

Harris, N. R. P., Rex, M., Goutail, F., Knudsen, B. M., Manney, G. L., Müller, R., and von der Gathen, P.: Comparison of empirically derived ozone losses in the Arctic vortex, J. Geophys. Res., 107, doi:10.1029/2001JD000482, 2002.

Knudsen, B. M. and Grooss, J.-U.: Northern mid-latitude stratospheric ozone dilution in spring modeled with simulated mixing, J. Geophys. Res., 105, 6885-6890, 2000.

Knudsen, B. M., Larsen, N., Mikkelsen, I. S., Morcrette, J.-J., Braathen, G. O., Kyrö, E., Fast, H., Gernandt, H., Kanzawa, H., Nakane, H., Dorokhov, V., Yushkov, V., Hansen, G., Gil, M., and Shearman, R. J.: Ozone depletion in and below the Arctic vortex for 1997, Geophys. Res. Lett., 25, 627-630, 1998.

Lait, L. R.: An Alternative Form for Potential Vorticity, J. Atmos. Sci., 51, 1754-1759, 1994.

Lary, D. J., Chipperfield, M. P., Pyle, J. A., Norton, W. A., Riishøjgaard, L. P.: Three-dimensional tracer initialization and general diagnostics using equivalent PV latitude-potentialtemperature coordinates, Q. J. R. Meteorol. Soc., 121, 187-210, 1995.
Morcrette, J.-J.: Radiation and Cloud Radiative Properties in the ECMWF Operational Weather Forecast Model, J. Geophys. Res., 96, 9121-9132, 1991.

Müller, M., Neuber, R., Fierli, F., Hauchecorne, A., Vömel, H., and Oltmans, S. J.: Strotospheric water vapour as tracer for Vortex filamentation in the Arctic winter 2002/2003, Atmos. Chem. Phys., 3, 1991-1997, 2003,

SRef-ID: 1680-7324/acp/2003-3-1991.

Nash, E. R., Newman, P. A., Rosenfield, J. E., and Schoeberl, M. R.: An objective determination of the polar vortex using Ertel's potential vorticity, J. Geophys. Res., 101, 9471-9478, 1996.

Ray, E. A., Moore, F. L., Elkins, J. W., Hurst, D. F., Romashkin, P. A., Dutton, G. S., and Fahey, D. W.: Descent and mixing in the 1999-2000 northern polar vortex inferred from in situ tracer measurements, J. Geophys. Res., 107, doi:10.1029/2001JD000961, 2002.

Rex, M., Salawitch, R. J., Harris, N. R. P., von der Gathen, P., Braathen, G. O., Schulz, A., Deckelmann, H., Chipperfield, M., Sinnhuber, B.-M., Reimer, E., Alfier, R., Bevilacqua, R., Hoppel, K., Fromm, M., Lumpe, J., Küllmann, H., Kleinböhl, A., Bremer, H., von König, M., Künzi, K., Toohey, D., Vömel, H., Richard, E., Aikin, K., Jost, H., Greenblatt, J. B., Loewenstein, M., Podolske, J. R., Webster, C. R., Flesch, G. J., Scott, D. C., Herman, R. L., Elkins, J. W., Ray, E. A., Moore, F. L., Hurst, D. F., Romashkin, P., Toon, G. C., Sen, B., Margitan, J. J., Wennberg, P., Neuber, R., Allart, M., Bojkov, B. R., Claude, H., Davies, J., Davies, W., De Backer, H., Dier, H., Dorokhov, V., Fast, H., Kondo, Y., Kyrö, E., Litynska, Z., Mikkelsen, I. S., Molyneux, M. J., Moran, E., Nagai, T., Nakane, H., Parrondo, C., Ravegnani, F., Skrivankova, P., Viatte, P., and Yushkov, V.: Chemical depletion of Arctic ozone in winter 1999/2000, J. Geophys. Res., 107, doi:10.1029/2001JD000533, 2002.

Rex, M., Salawitch, R. J., von der Gathen, P., Harris, N. R. P., Chipperfield, M. P., and Naujokat, B.: Arctic ozone loss and climate change, Geophys. Res. Lett., 31, doi:10.1029/2003GL018844, 2004.

Singleton, C. S., Randall, C. E., Chipperfield, M. P., Davies, S., Feng, W., Bevilacqua, R. M., Hoppel, K. W., Fromm, M. D., Manney, G. L., and Harvey, V. L.: 2002-2003 Arctic ozone loss deduced from POAM III satellite observations and the SLIMCAT chemical transport model, Atmos. Chem. Phys. Discuss., 4, 7011-7045, 2004,

SRef-ID: 1680-7375/acpd/2004-4-7011.

Sobel, A. H., Plumb, R. A., and Waugh, D. W.: Methods of Calculating Transport across the Polar Vortex Edge, J. Atmos. Sci., 54 2241-2260, 1997.

Tilmes, S., Müller, R., Grooß, J.-U., Höpfner, M., Toon, G. C., and Russell III, J. M.: Very early chlorine activation and ozone loss in the Arctic winter 2002-2003, Geophys. Res. Lett., 30, doi:10.1029/2003GL018079, 2003.

Tilmes, S., Müller, R., Grooß, J.-U., and Russell III, J. M.: Ozone loss and chlorine activation and ozone loss in the Arctic winters 1991-2003 derived with the tracer-tracer correlations, Atmos. Chem. Phys., 4, 2181-2213, 2004,

SRef-ID: 1680-7324/acp/2004-4-2181. 